\title{
SURVEI JENTIK NYAMUK Aedes spp DI DESA TEEP KECAMATAN AMURANG BARAT KABUPATEN MINAHASA SELATAN
}

\author{
${ }^{1}$ Tampi F.H \\ ${ }^{2}$ Runtuwene J \\ ${ }^{3}$ Pijoh V.D
}

\author{
${ }^{1}$ Kandidat Skripsi Fakultas Kedokteran Universitas Sam Ratulangi Manado \\ ${ }^{2}$ Bagian Parasitologi Fakultas Kedokteran Universitas Sam Ratulangi Manado \\ Email: drummerdrum1@yahoo.co.id
}

\begin{abstract}
Aedes spp mosquito have a huge role a vector for spreading diseases such as yellow fever, dengue fever and chikungunya. This type of mosquito thrive in an environment like a settlement. Teep village have a big potential to harbor this type of mosquito. This research is using a retrospective descriptive study that present an overall view of the density and the type of larvae based on the gathered information such as number of the houses and type of host site. There is two kind of host site one is TPA and the other is non TPA, with a figure of TPA 6 host site $(28,56 \%)$ and non TPA 15 host site $(71,44 \%)$. Two variety of mosquito that have been found is Aedes aegypti $(57,14 \%)$ and Aedes albopictus $(42,86 \%)$. Based on the mosquito density figure the result shown that House index is $12,35 \%$, container index is $5 \%$, Breatau index is 12,35\%, and Angka Bebas Jentik is $87,64 \%$. Aedes spp larvae most commonly found on the non TPA host site rather than TPA host site. There is no big wedge of margin between the Aedes aegypti larvae and Aedes albopictus that have been found on Teep village. House index, Container index, Breautau index in Teep village is just above average.
\end{abstract}

Keyword: Aedes spp larvae.

Abstrak: Nyamuk Aedes spp mempunyai dampak pada bidang kesehatan sebagai vektor utama penyakit demam kuning (Yellow Fever), Demam Berdarah Dengue dan Chikungunya. Nyamuk tipe ini mempunyai kebiasaan bertelur di tempat perindukan dekat dengan pemukiman masyarakat. Desa Teep merupakan salah satu desa yang berpotensial sebagai habitat dari nyamuk Aedes spp. Penelitian ini adalah penelitian survey deskriptif dan menggunakan metode cross sectional yang memaparkan gambaran kepadatan dan jenis jentik berdasarkan rumah dan Tempat Penampungan Air (TPA) yang diperiksa. Pemeriksaan jentik di rumah-rumah dilakukan pada dua jenis perindukan yaitu perindukan TPA dan perindukan non TPA. Jumlah perindukan yang positif jentik yaitu : TPA 6 perindukan (28,56\%) dan non TPA 15 perindukan (71,44\%). Terdapat dua varian nyamuk Aedes spp yang ditemukan yaitu jentik Aedes aegypti (57,14\%) dan jentik Aedes albopictus (42,85\%). Berdasarkan hasil pengukuran kepadatan jentik, didapatkan House Index (HI) sebesar 12,35 \%, Container Index (CI) sebanyak 5\%, Breatau Index (BI) 12,35\%, dan Angka Bebas Jentik (ABI) sebanyak 87, 64\%. Jentik Aedes spp lebih banyak ditemukan pada tempat perindukan nonTPA dibandingkan dengan tempat perindukan TPA. Perbandingan populasi jentik Aedes aegypti dan Aedes albopictus di Desa Teep tidak berbeda jauh.

Kata kunci: Jentik Aedes spp.

Dari Secara global masalah kesehatan masih merupakan sebuah problema yang besar. Hal tersebut dapat dibuktikan dengan meningkatnya jumlah penyakit menular yang semakin menjadi-jadi. Fenomena ini disebabkan karena peningkatan jumlah 
penduduk dan bertambahnya pemukiman di berbagai pelosok dunia. Salah satu penyakit menular yang yang berkembang seiring dengan jumlah pemukiman ialah Demam Berdarah Dengue (DBD). Beberapa dekade belakangan ini jumlah kasus DBD telah menunjukan peningkatan yang dramatis baik di luar maupun di dalam negeri. Penyakit ini secara langsung memberi dampak negatif pada kehidupan ekonomi dan sosial masyarakat. DBD merupakan penyakit yang ditularkan pada manusia melalui gigitan nyamuk penular (vektor), dengan Aedes aegypti sebagai vektor utama, diikuti oleh Aedes albopictus sebagai vektor potensial. ${ }^{1,2}$

Aedes aegypti merupakan vektor utama dari penyakit DBD, selain vektor potensial lainnya yaitu Aedes albopictus. Aedes aegypti umumnya memiliki habitat di lingkungan perumahan, di mana terdapat banyak genangan air bersih dalam bak mandi ataupun tempayan. Oleh karena itu, jenis ini bersifat urban, bertolak belakang dengan Aedes albopictus yang cenderung berada di daerah hutan berpohon rimbun. penyebaran populasi Aedes aegypti dipengaruhi oleh faktor musim, peningkatan biasanya terjadi pada saat musim hujan, karena larva membutuhkan air yang cukup untuk perkembangannya. ${ }^{1}$

Desa Teep merupakan salah satu Desa yang berpotensial sebagai habitat dari nyamuk Aedes. Pada Desa ini terdapat tempat-tempat yang berpotensial menjadi tempat perindukan larva yang pada umumnya merupakan tempat bertelur dari nyamuk Aedes Teep merupakan Desa yang berada di Kecamatan Amurang Barat. Dengan jumlah kepala keluarga 380 dan jumlah rumah \pm 276 . Batas-batas Desa Teep yaitu sebelah utara: pantai, sebelah timur: Desa Kapitu, sebelah barat: Desa Tawaang dan sebelah selatan berbatas dengan jalan trans Sulawesi. Desa ini umumnya terdiri dari lingkungan permukiman yang merupakan tempat penyebaran dari nyamuk Aedes aegypti.

Teep merupakan desa yang berada di kabupaten minahasa selatan di mana jumlah penderita DBD di Kabupaten Minahasa Selatan, dari Desember 2005 sampai dengan
21 Januari 2008 dengan ialah 100 penderita dengan angka kefatalan kasus (CFR) sebesar 0\% dan jika dibandingkan dengan jumlah penderita pada tahun-tahun sebelumnya, tahun 2008 menunjukan angka tertinggi. ${ }^{3}$

\section{METODOLOGI}

Penelitian ini adalah penelitian survei deskriptif dengan menggunakan metode cross sectional. Penelitian ini dilakukan di Desa Teep, kecamatan Amurang barat Kabupaten Minahasa Selatan dan pemeriksaan sampel dilakukan di laboratorium Parasitologi Universitas Sam Ratulangi Manado. Penelitian ini dilaksanakan di selama bulan Desember 2011 sampai Januari 2012. Dalam penelitian ini populasi yang di ambil adalah rumah yang berada di Desa Teep. Cara perhitungan sampel berdasarkan pada Pedoman Survei Entomologi Demam Berdarah Dengue Departemen Kesehatan R.I. Variabel penelitian menggunakan indeks-indeks jentik (house index, container index breatau index dan angka bebas jentik).

Hasil survey kemudian diteliti di laboratorium parasitologi dengan cara identifikasi berikut ini:

1. Larva dikeluarkan dari kantong plastik dengan pipet.

2. Larva kemudian direndam berturut-turut dalam alcohol 70\%, 80\%, 96\% absolut masing-masing 10 menit.

3. Larva dipindahkan pada parutan xylol selama 1 jam.

4. Larva diletakkan dalam kaca objek.

5. Pada larva dilakukan maunting dengan kanada balsem.

6. Larva diidentifikasi di bawah mikroskop cahaya dengan pembesaran 10x menggunakan kunci larva Aedes.

\section{HASIL}

Dari hasil penelitian yang dilakukan terhadap 170 rumah, ditemukan yang positif terdapat jentik berjumlah 21 rumah (Gambar 1).

Pemeriksaan jentik di rumah-rumah dilakukan pada 2 jenis perindukan yaitu perindukan TPA dan perindukan non TPA. 
Dengan jumlah perindukan TPA sebanyak 173 dan non TPA 148 perindukan (Gambar 2).

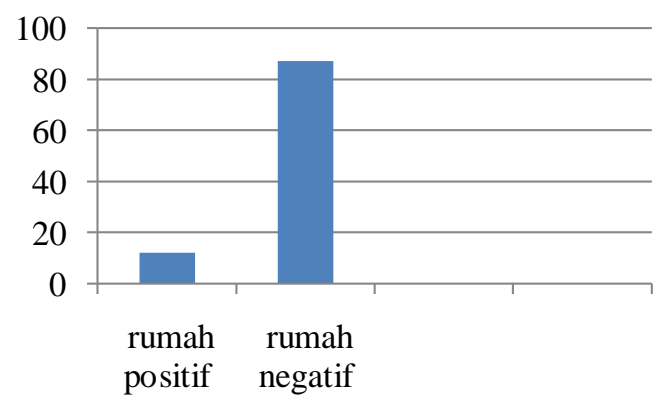

Gambar 1. Presentase jumlah rumah yang positif jentik.

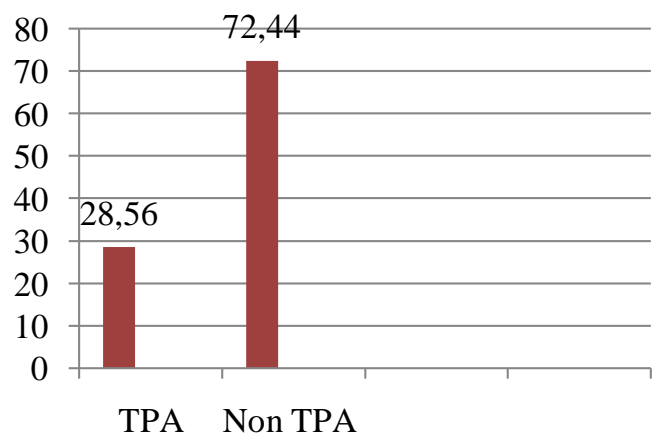

Gambar 2. Presentase jenis perindukan yang positif.

Dari hasil penelitian yang dilakukan pada jentik-jentik yang diteliti, ditemukan adanya keragaman jenis larva yang dapat dilihat pada tabel di bawah ini.

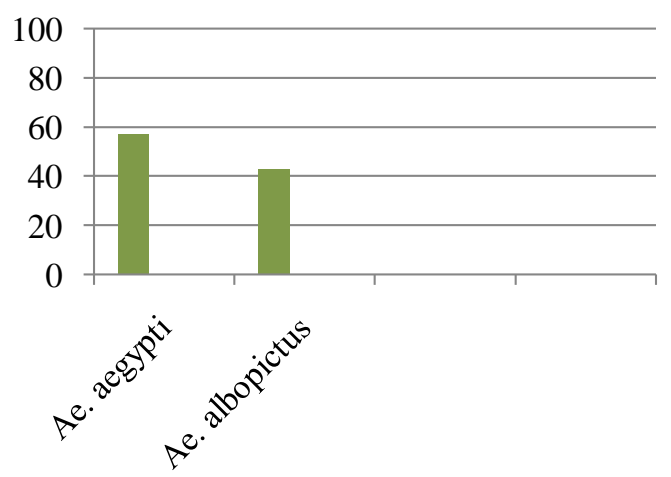

Gambar 3. Presentase jenis jentik yang ditemukan.

\section{BAHASAN}

Dari penelitian yang dilakukan, jumlah rumah yang positif terdapat jentik berjumlah 12,35 \%. Nilai ini tidak berbeda jauh dibandingkan dengan survei jentik yang dilakukan oleh Anastasia Sentiwono di Malalayang I di mana jumlah rumah yang positif larva adalah 14\%. Kesamaan ini mungkin dapat disebabkan oleh jenis perindukan yang diteliti, Desa Teep dan Kelurahan Malalayang I mempunyai presentase jumlah perindukan non TPA yang relatif sama.

Di lihat dari hasil penelitian di atas bahwa total nilai yang diperoleh pada penelitian di perindukan yaitu TPA 28,57\% dan non TPA 71,44\%. Nilai ini tidak berbeda jauh dengan penelitian yang dilakukan di 9 negara tropis oleh WHO dengan peneliti Dana A. dkk. Di daerah pesisir pantai Ao Thong Nai Pan (Vietnam) jumlah TPA yang positif adalah 31\% sedangkan jumlah non TPA yang positif 69\%. Kedua hasil penelitian menunjukan ternyata perindukan non TPA lebih banyak mengandung jentik positif dibandingkan perindukan TPA. Menurut Bond dan Fay kepadatan pada jentik Aedes dipengaruhi oleh faktor jenis, warna, dan kemampuan menyerap air dari perindukan. Dinding non TPA yang kasar merupakan tempat bertelur yang sangat disukai nyamuk Aedes, sebaliknya dinding TPA yang licin tidak disukai nyamuk betina untuk bertelur. Di Desa Teep pada umumnya perindukan non TPA yang diperiksa tidak mempunyai dinding yang licin sehingga lebih disenangi oleh nyamuk Aedes. Sedangkan tempat perindukan TPA di Desa Teep umumnya terbuat dari keramik, salah satu karakteristik keramik yang menojol adalah permukaan dinding yang licin ${ }^{4,5}$

Tempat penampungan air (TPA) yang diperiksa, berturut-turut nilai presentase yang diperoleh adalah : drum sebesar 100\%, bak mandi 2,89\%, ember/loyang 2,23\%, bak WC 1,75\% Jika melihat nilai presentase dari masing-masing jenis TPA, nilai yang diperoleh pada TPA jenis drum sangat tinggi yaitu 100\%. Hasil ini sesuai dengan penelitian yang telah dilakukan sebelumnya 
di Kota-Kota pelabuhan di Venezuela dengan persentase drum yang positif jentik rata-rata lebih dari $80 \%{ }^{5}$

Drum menjadi tempat perindukan TPA yang paling banyak ditemukan larva karena drum mempunyai dinding permukaan yang kasar dan luas, selain itu drum juga pada umumnya mempunyai warna dasar yang gelap. Drum masuk dalam kategori mother loci. Mother loci adalah sebutan untuk perindukan-perindukan dengan karakteristik utama sebagai tempat hidup nyamuk yang produktif. Perindukan-perindukan yang seperti ini biasanya banyak berada di daerah urban. ${ }^{5}$

Drum digunakan sebagai tempat penampungan air cadangan yang dibutuhkan untuk keperluan sehari-hari, tetapi dalam penggunaanya sering dipakai bukan untuk menampung air minum ataupun air bersih, sehingga tidak habis terpakai dan kurang dibersihkan, dan sisa air yang dibiarkan cukup lama tanpa ditutup rapat, memungkinkan nyamuk Aedes bertelur dan berkembang biak menjadi jentik. Jika dibandingkan perindukan TPA lain seperti bak mandi bak wc dan ember/loyang, tempat-tempat penampungan air ini lebih mudah dikuras. Air yang di tampung di dalamnya hampir selalu habis terpakai dan selalu diperhatikan untuk ditutup dan dijaga kebersihannya. Satu-satunya ember yang terdapat larva telah lama airnya tidak digunakan.

Pada tempat perindukan non TPA hasil penelitian yang diperoleh, loyang/ember dan pot bunga bekas memiliki nilai paling tinggi yaitu 11,11\%, kemudian kaleng bekas dengan presentase 8,82 \% . Ember/loyang yang dibiarkan dihalaman dan tidak dikuburkan atau di simpan disukai nyamuk Aedes sebagai tempat perindukannya sebab air dalam ember/loyang bekas tidak dibuang dan tidak diperhatikan. Terlihat bahwa perindukan non TPA memiliki nilai total lebih tinggi dibandingkan dari perindukan TPA, hal ini di sebabkan karena barang bekas kebanyakan diletakan di luar rumah dan halaman sehingga kurang di perhatikan kebersihannya dan jika dibiarkan tertampung air, baik air hujan, sumur atau
PAM, maka air yang diam didalamnya tidak digunakan sehingga dijadikan tempat bertelur oleh nyamuk Aedes aegypti, hal ini sesuai dengan pola bertelur Aedes aegypti yang suka bertelur pada air yang tersimpan lama serta tidak dipakai.

Berdasarkan hasil identifikasi larva, jenis jentik Aedes yang ditemukan mempunyai varian yang hampir sama. Presentase jentik Aedes aegypti adalah 57,14\% sedangkan jentik Aedes albopictus adalah 42,85\%. Hasil ini mempunyai kesamaan dengan penelitian yang di lakukan oleh P. Duta pada area Moreh bagian India selatan di mana Aedes aegypti didapatkan mempunyai presentase $64 \%$ dan Aedes albopictus 46\% Kesamaan ini disebabkan oleh letak dari Desa Teep dan Desa Moreh kedua-duanya merupakan daerah semiurban. Walaupun Desa Teep merupakan tempat permukiman penduduk, tetapi masih terdapat lahan-lahan yang dipenuhi oleh banyak pohon yang rindang, selain itu desa ini dekat dengan kumpulan hutan. Aedes albopictus lebih menyukai tempat di luar rumah yaitu hidup di pohon atau kebun atau kawasan pinggir hutan. ${ }^{4}$

Berdasarkan hasil pengukuran kepadatan larva, didapatkan House Index (Hl) sebesar 12,35 \%, Container Index (CI) sebanyak 5, \% Breatau Index (B1) 12,35\%, dan Angka Bebas Jentik (ABJ) sebanyak 87, 64\%. Jika dibandingkan dengan hasil penelitian yang dilakukan Anastasia Sentiwono pada tahun 2002 di daerah Malalayang I yang merupakan daerah endemis DBD didapatkan HI sebanyak $14,28 \%$ CI sebanyak 7,30\% BI sebanyak $26,08 \%$. Dari hasil penelitian angka ratarata $\mathrm{Hl}, \mathrm{CI}$, BI tidak jauh berbeda dengan hasil penelitian yang dilakukan di Desa Teep. Jadi besar kecilnya nilai HI, CI, dan BI kurang/tidak terlalu berpengaruh terhadap banyaknya kasus DBD yang terjadi tetapi tergantung pada ada tidaknya virus dengue dalam tubuh nyamuk Aedes aegypti didaerah tersebut. Hal ini mungkin karena tubuh nyamuk Aedes aegypti di Desa Teep tidak mengandung virus dengue. Sedangkan di daerah Malalayang I yang merupakan derah endemis cukup tinggi dengan nyamuk 
Aedes aegypti yang mengandung virus dengue sehingga dapat menjadi vektor dalam penularan DBD. Di Desa Teep terdapat sedikit kasus DBD, angka rata-rata HI, CI, dan BI yang diperoleh tidak terlalu besar sehingga kemungkinan nyamuk Aedes tidak membawa virus dengue.

\section{SIMPULAN}

Setelah dilakukan penelitian deskriptif dengan metode cross-sectional pada desa Teep dapat disimpulkan bahwa larva Aedes lebih banyak ditemukan pada tempat perindukan non TPA dibandingkan dengan tempat perindukan TPA. Perindukan yang mempunyai potensi tertinggi tempat bertelur nyamuk di Desa Teep adalah drum, dengan bak WC sebagai perindukan dengan potensi terendah. Hasil menunjukan perbandingan populasi larva Aedes aegypti dan Aedes albopictus di Desa Teep tidak ada perbedaan yang jauh.

\section{DAFTAR PUSTAKA}

1. Safar R. Parasitologi Kedokteran: Nurhayati N, editor. Protozoologi Helmintologi dan Entomologi. Bandung:
Balai penerbit Yrama Widya, 2010; p.259265.

2. Michel B. Dengue Guideline for Diagnosis, Treatment, Prevention and Control. Geneva: WHO [homepage on the Internet]. 2009 [cited 2011 Dec]. Available from http://whqlibdoc.who.int/publications/2009/ 9789241547871_eng.pdf.

3. Dinas Kesehatan Propinsi Sulawesi Utara. Profil kesehatan provinsi Sulawesi Utara [homepage on the Internet]. 2008 [cited 2013 Jan]. Available from http://www.depkes.go.id/downloads/profil/p rov_sulut_2008.pdf

4. Duta P. Potential Vectors of Dengue and the Profile of Dengue in the North-Eastern Region of India An Epidemiological Perspective [homepage on the Internet]. Nodate [cited 2011 Dec]. Available from http://209.61.208.233/LinkFiles/Dengue_Bu lletins_c29.pdf.

5. Dana A. Multicountry study of Aedes aegypti pupal productivity survey methodology: findings and recommendations. Gainsville: WHO [homepage on the Internet]. 2006 [cited 2011 Dec]. Available from http://www. who.int/tdr/publications/documents/aedes_a egypti.pdf. 